\title{
Putaran Uruguay, Integrasi Ekonomi Regional dan Implikasinya bagi Indonesia
}

\author{
Oleh : Edy Suandi Hamid
}

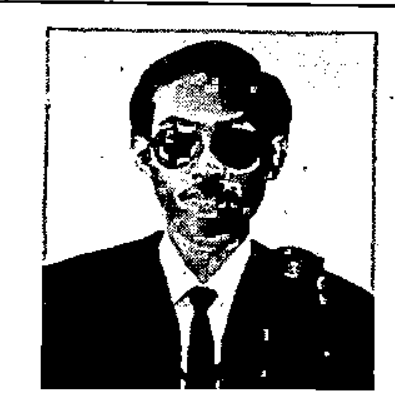

Edy Suandl Hamid, adalah Dosen Negeri yang dipekerjakan pada Fakultas Ekonomi Universitas Islam Indonesia, disamping juga sebagai staf peneliti pada PusatPenelitian Pembangunan Pedesaan dan Kawasan (P3PK) UGM dan Sekretaris Ikatan Sarjana Ekonomi Indonesia DIY. Lahir di Tanjung Enim, 11 Desember 1957, dan menyelesaikan studi pembangunan (Umum)tahun 1983 S-1 serta S-2 dari Faculty of Economic Thammasat University, Bangkok 1990.

Pemah menjadi wartawan dan redaksiekonomiKedaulatan Rakyat, serta Pimpinan Redaksi Majalah Equilibrium (FE UGM). Kini aktif dalam kegiatan penelitian yang menyangkut masalah pedesaan. Menulis buku Pengantar TeoriPerilakuKonsumen (bersama Drs. Effendy Ari, 1985), menyunting buku Kredit Pedesaan di Indonesia (bersama Prof. Mubyarto, 1986) dan Meningkatkan Efisiensi Nasional (bersama Prof. Mubyarto, 1987).

Pengertian dan Sejarah Singkat GATT

GATT (General Agreement on Tariffs and Trade) Perjanjian Umum tentang Tarif dan Perdagangan merupakan perjanjian multilateral yang tujuan utamanya adalah untuk membebaskan perdagangan dunia dari berbagai faktor yang mungkin 'menghambatnya, . serta menempatkannya padasuatu landasan yang kokoh, sehingga dapat menumbuhkan dan mengembangkan perekonomian serta kesejahteraan bangsa-bangsa di dunia. GATT mulai dinundingkan sejak tahun 1974, dan mulai diberlakukan oleh 23 negara yang pertama-tama menandatanganinya pada tanggal 1 Januari 1948.
Sejak itu pula GATT ini berperan sebagai lembaga yang menggerakkan pérundinganperundingan guna mewujudkan suatu perdagangan yang bebas dan adil. Dengan prinsip perdagangan bebas tanpa hambatan ini diharapkan terjadi efisiensi dalam perekonomian dunia. Dalam GATT pula, yang kini anggotanya mencapai 117 negara, negara-negara anggotanya mendiskusikan dan merundingkan masalah perdagangannya.

Prinsip dan aturan perdagangan - multilateral dalam GATT ini pada dasamya terdiri dari tiga hal pokok (lihat Soedradjat Djiwandono, 1992), Pertama, prinsip resiprositas atau timbal balik, artinya, perlakuan yang diberikan suatu negara 
kepada negara lain, harus diimbangi dengan perlakuan yang sama dari negara lain ke mitra dagangnya tersebut. Kedua, prinsip non-diskriminasi atau perlakuan yang sama. Prinsip ini dikenal pula dengan sebutan mostfaoured nation (MFN) yang maknanya adalah apabila kita mengistimewakan suatu negara, maka keistimewaan itu juga harus diberikan kepada negara lainnya. Prinsip Ketiga, adalah transparancy atau kejelasan dan keterbukaan, artinya, perlakuan dan kebijaksanaan yang dilakukan suatu negara harus transparan, jelas dan dapat diketahui mitra dagangnya. Hal ini dilaksanakan dengan cara memberikan pelaporan kepada Sekretarian GATT yang ada di Geneva mengenai kebijaksanaan dan perubahan kebijaksanaan perdagangannya. Sehingga apabila ada negara yang membutuhkan penjelasan mengenai kebijaksanaan tersebut, maka negara yang bersangkutan harus melayaninya.

Prinsip pokok di atas menjadi dasar pijakan dalam perundingan-perundingan perdagangan multilateral anggota GATT. Namun demikian dalam kenyataannya hal itu masih mungkin disimpangi, dengan berbagai persyaratan tertentu. Dalam mengurangi hambatan pērdagangan dunia . ini, GATT tidak saja berkonsentrasi pada masalah hambatan tarif bea masuk, melainkan juga hambatan-hambatan yang berkaitan dengan non-tariff atau NonTariff Barriers (NTB) yang banyak diberlakukan oleh negara-negara anggotanya. Masalah-masalah yang berkaitan dengan pengurangan dan penghapusan tingkat tarif dan hambatan non-tarif tersebut menjadi bahasan utama dalam tujuh putaran-putaran perundingan yang dilaksanakan sejak 1947 (di Jenewa) hingga Putaran Tokyo (1973-1979). Putaran yang terakhir dilakukan adalah Putaran Uruguay (Urguay Round), yang dianggap perundingan paling ambisius karena mélingkupi banyak aspek yang berkaitan dengan tata perdagangan dunia.

Untuk melaksanakan aktivitas atau melakukan perundingan-perundingan, GATT memiliki beberapa forum dan lembaga yang mendukungnya. Forum atau badan tertinggi GATT adalah sidang para anggota atau sidang contracting parties, yang biasanya diadakan setiap tahun. Lembaga-lembaga GATT antara lain adalah Dewan Perwakilan (Council Representative), yang mempunyai kewenangan untuk menangani hal yang rutin dan mendesak; Committee on Trade and Development, Committee on Balance of Payment, Committee on Participating Countries, Committee on Tariff Concession, Committee on Safeguard dan sebagainya.

Walaupun belum sepenuhnya berhasil mewujudkan tujuan yang digariskannya, namun GATT sudah memberikan kontribusi cukup besar dalam merintis perwujudan perdagangan dunia yang lebih bebas, jujurdan adil. Berhasilnya kesepakatan dalam Putaran Uruguay telah memberikan harapan lebih besarpuladalam penciptaan perdagangan yang lebih bebas tersebut.

\section{Uruguay Round (Putaran Uruguay)}

Putaran Uruguay diluncurkan pertama kali pada forum tingkat Menteri di Punta del Este, Uruguay pada tanggal 20 September 1986. Tujuan Putaran Uruguay antara lain adalah: (1) menciptakan perdagangan yang bebas yang diharapkan dapat memberikan manfaat bagi semua 
negara, khususnya negara berkembang; (2) meningkatkan peran GATT dan memperbaiki sistem perdagangan multilateral berdasarkan prinsip-prinsip dan ketentuan-ketentuan GATT serta memperluas cakupan produk perdagangan dunia; (3) meningkatkan ketanggapan sistem GATT terhadap perkembangan situasi perekonomian dengan memperlancar penyesuaian struktural, mempercepat hubungan GATT dengan. organisasi internasional yang relevan dengan mengingat prospek perdagangan di masa datang; (4) mengembangkan suatu bentuk kerjasama pada tingkat nasional dan internasional untuk mengaitkan hubungan antara kébijaksanaan perdagangan dengan kebijaksanaan ekonomi lain melalui usaha untuk memperbaiki sistem moneter intemasional (Sukardi, 1994).

Setelah berjalan berlarut-larut dan berkali-kali pula terancam gagal, forum perundingan anggota GATT untuk membahas rencana konkret tentang pelaksanaan perdagangan dunia yang bebas, adil dan terbuka tersebut, akhirnya disepakati tanggal 15 Desember 1993. Dengan hasil akhir Putaran Uruguay ini, dan telah pula diratifikasi pada bulan April 1994 di Marakesh, negara-negara anggota (contracting parties) GATT harus pula secara bertahap melaksanakan berbagai ketentuan yang disepakati itu. Bagi yang takkonsisten dengan kesepakatan tersebut, akan mempunyai konsekuensi dapat dikucilkandari tata perdagangan dunia atau multilateral.

Sebagaimana disinggung di atas, Putaran Uruguay tersebut telah membahas upaya yang berkaitan untuk menghapuskan proteksionisme, memperluas perdagangan intemasional, memperkuat posisi GATT dalàm menangani masalah perdagangan multilateral serta memperkuat kerjasama internasional yang mendukung perkembangan ekonomi dunia. Forum ini sejak awalnya telah menjadi fokus perhatian dunia, mengingat materi yang dibahas sangat penting dan menentukan perkembangan ekonomi dunia secara keseluruhan.

Jika dilihat dari kesepakatan yang ada, maka apa yang telah dihasilkan dari Putaran Uruguay ini memang sangat luas cakupannya, dan diurai secara cukup detail, konkret dan praktis: Secara rinci, Putaran Unuguay melingkupi lima belas aspek permasalahan, mulai dari masalah tarif, subsidi, ketentuan tentang perdagangan berbagaikomoditi (produk tropis, pertanian, tekstil), hingga tentang penyelesaian sengketa dagang bilateral maupun multilateral.

Dengan demikian, ini merupakan suatu dokumen operasional yang cukup mengikat negara penanda tangan (contacting parties) untuk mematuhinya. Oleh karena itu, anggota GATT tadinya sangat berhati-hati untuk. menyepakati materi Putaran Uruguay ini. Akibatnya, tidak mengherankan kalau forum ini menjadi berlarut-larut serta berkali-kali terancam gagal karena adanya negara yang ngotot untuk menghilangkan atau memodifikasi ketentuan yang dianggap merugikan negaranya. Misalnya yang berhubungan dengan subsidi di sektor pertanian, yang ditantang keras oleh negara anggota Masyarakat Eropa (ME). Bertele-telenya forum inilah yang menyebabkan timbul sindiran pada-GATT yang memayungi 
Putaran Uruguay tersebutsebagai "General Agreement on Talk and Talk" atau sekedar forum omong kosong yang tak berkesudahan. Bahkan adanya akselerasi -dalam pembentukan APEC (Asia Pacific Economic Cooperation) tidak lepas dari adanya kekhawatiran dari ğagaínya Putaran Uruguay tersebut.

Namundemikian, akhimya berbagai rancangan yang ada déngan modifikasi di sana-sini dapat disetujui para anggota. Forum Putaran Uruguay berakhir dengan antara lain kesepakatan untuk membentuk World Trade Organization (WTO) atau Organisasi Perdagangan Dunia(OPD), yang mulai memberlakukannya I Januari 1995. WTO ini berfungsi antara lain untuk memperlancar pelaksanaan administrasi danoperasional untuk mewujudkan sasaran dari organisasi tersebut; menyediakan forum perundingan multilateral anggotanya; mengatur kesepakatan mengenai Tata Tertib Aturan dan prosedur Penyelesaian Sengketa; mengatur -mekanisme pemantauan kebijaksanaạn perdagangan; serta bekerja sama dengan Dana Moneter Internasional (IMF), Bank Dunia serta badan afiliasinya dalam rangka menciptakan keterkaitan yang lebih besar dalam kebijaksanaan ekonomi global.

Di samping pembentukan WTO.PU juga telah melakukan interpretasi bari mengenai berbagai pasal perjanjian GATT 1947; menambah cakupan perjanjian GATT yang meliputi hasil pertanian, tekstil dan pakaian jadi, perdagangan jasa, aturan hak milik intelektual yang berkaitan dengan perdagangan(TRIPs), aturan investasi yang berkaitan dengfan perdagangan (TRIMs), serta melakukan kesepakatan baru mengenai berbagai aturan perdagangan (rules making). Pada prinsipnya kesepakatan-kesepakatan tersebut dimaksudkan untuk melakukan perbaikan atas akses pasarbagi lalulintas perdagangan barang dan jasa di dunia.

Dengan perdagangan yang lebih. bebas dari hasil Putaran Uruguay, diperkirakan akan memberikan beberapa dampak positif bagi perekonomian dunia. Dampak tersebut antara lain (1) adanya kenaikan ekstra produk domestikbruto US\$ 230 miliar pada tahun 2005; (2) kenaikan ekstra perdagangan barang sebesar $12 \%$ atau US\$745 miliar (dengan dollar tahun 1992); (3) keunggulan komparatif ekonomi akan berubah, gelombang baru relokasi industri mendapat dorongan; dạn (4) dampak läinnya yang bersifat kualitatif seperti tarifikasi dan penguatan disiplin (Miranda Goeltom, 1994). Pendapatan dan perdagangan ini tidak sama dinikmati oleh setiap negara anggotanya. Seberapa besar manfaat yáng dinikmati oleh masingmasing negara tersebut sangat tergantung pada kesiapannya dalam mengantisipasi perkembangan yang ada sebagai akibat dari liberalisasi perdagangan dunia. Bahkan sangat mungkin negara yang tidăk. siap mengantisipasi kebebasan tersebut tidak memperoleh manfaat positif dan Putaran Uruguay, melainkan mengalami kerugian sebagai akibat dari ketidakefisienan industrinya dan kekalahánnya dalam kompetisi dagang di pasar domestik yang kian terbuka serta di pasar global yang persaingannya semakin ketat pula.

\section{GATT/Putaran Uruguay dañ Regionalisasi Ekonomi}

Salah satu kekhawatiran yang membayangi pelaksanaan hasil Putaran 
Uruguay adalahberkembangnya kelompokkelompok ekonomi regional yang mengarah pada trading block. Hal ini dkhawatirkan akan menghambat lalulintas perdagangan yang bebas di tingkat global, karena kemungkinan negara anggota blok-blok dagang itu akan mementingkan perdagangan antar mereka, dan kian protektif terhadap negara di luar bloknya. -Kelompok regional yang mengarah pada blok-blok dagang memang merupakan. aktivitas yang tidak dapat dibenarkan menurut ketentuan umum GATT.

Namun demikian Article XXIV GATT tidakmelarang adanya pembentukan kerjasama regional, seperti persekutuan pabean (c̄ustoms union), free trade area, pasar bersama dan sejenisnya sepanjang dalam jangka panjang di arahkan kepada perdagangan bebas global. Adanya integrasi ekonomi regional itu tidak diperkenankan jika dibarengi dengan penirigkatan atau penciptaan hambatan-hambatan bagi negara di luar kelompoknya. Article XXIV GATT ini termasuk yang ditinjau atau diinterpretasikan kembali dalam Putaran Unuguay.

Dalam hal penetapan tarif, maka evaluasi akan dilakukan Sekretariat GATT untuk melihat sejauhmana sudah sejalan dengan ketentuan dan mekanisme yang digariskan, yang arahnya secara bertahap dapat menghilangkan diskriminasi tarif yang ada. Ditegaskan pula tentang penyesuaian tarif yang tercantum dalam Pasal XXIV (5:c) bahwa jadwal penyesuaian tersebut adalah maksimal 10 tahun. Namun jangka waktu itú dapat melebihi 10 tahun hanya dalam hal-hal tertentu. Dalam hal suatu negara menyatakan bahwa 10 tahun tidak cukup, negara tersebut harus menyampaikan kepada Dewan Perdagangan untuk Barangbarang bahwa memerlukan waktu yang lebih lama.

Jadi adanya Masyarakat Ekonomi (EC), NAFTA (North-America Free Trade Area), AFTA (ASEAN Free Trade Area) dan sebagainya tetap dapat terus berjalan dalam era pasca Putaran Uruguay'sekarang ini. Namun demikian, sebagaimana tersurat dalam Pasal XXIV dari ketentuan GATT, arah kebijaksanaannya tetap pada perwujudan perdagangan bebas yang jujur, terbuka dan adil. Berbagai bentuk integrasi ekonomi regional ini merupakan langkah untuk menuju pada persaingan global.

Bagi negara-negara berkembang sebenamya integrasi ekonomi regional tersebut sangat penting sebagai exercise menuju ke kompetisi global. Jadi, hal seperti ini dapat difahami dalam konteks prilaku bagi negara berkembang. Negara-negara sedang berkembang, yang relatif tertinggal dalam pembangunan ekonominya, khususnya dalam industrialisasi mereka, akan sulit untuk langsung bersaing dengan negara yang telah maju lebih dulu atau yang sekarang dikenal dengan negaranegara industri. Untuk itu mèreka perlu membuat tahapan persaingannya dengan negara yang secara relatif kelasnya tidak jauh berbeda.

Kenyataannya integrasi ekonomi yang terjadi tak hanya dilakukan negara sedang berkembang, melainkan juga oleh negara-negara maju. Integrasi ini sudah dirasakan memberikan ganjalan dan hambatan bagi aliran barang dan jasa dunia untuk mengalir secara bebas dari negara satu ke negara lainnya. Persaingan antarnegara industri telah membuat mereka 
berupaya mencari mitra yang diharapkan dapat lebihmemberikan kepastian atas pasar produk mereka.

Adanya kenyataan demikian memang dapat memberikan ganjalan bagi pelaksanaan hasil.Putaran Uruguay atau bagi pelaksanaan tugas-tugas WTO nantinya. WTO harus benar-benar dapat berwibawa di mata semua anggotanya agar aturan main yang ada dapat berjalan. Tanpa adanya kewibawaan dan keberanian untuk memberikan sangsi kepada pelanggar ketentuan yang ada, maka akan dapat mengancam mandulnya pelaksanaan ketentuan-ketentuan dari kesepakatan yang ada. Hal ini tidak saja tergantung pada WTO, melainkan juga pada komitmen moral dari negara-negara industri. untuk menghormati segala kesepakatan yang sudah ditandatangani dalam PU tersebut.

\section{Implikasi bagi Indonesia}

Sebagai negarayang sedang memacu ekspornya, Indonesia sangat berkepentingan atas hasil dari Putaran Uruguay. Perkembangan industri yang 'terjadi saat ini membutuhkan akses untuk memasuki pasar dunia yang luas. Industri kita tak lagi melulu berorientasi ke dalam (inward looking), melainkan sudah semakin menuntut adanya pasar yang lebih luas di tingkat intemasional. Karenanya perlu ada pasar dunia yang terbuka dan bebas tanpa banyak macam proteksi.

Kenyataan yang dihadapi saat ini, berbagai barriers to entry ke pasar-pasar potensial kita banyak dibentang negaranegara: maju. Tekstil, yang merupakan komoditas nonmigas penghasil devisa terbesar Indonesia, tidak begitu mulus untuk menembus pasar di negara industri. Ada penetapan kuota dan pembatasan ekspor, yạng berarti mengganjal pertumbuhan sektor perstekstilan kita. Aturan yang menghambat ini, yang bertentangan dengan prinsip GATT, mendapat legitimasi di bawah payung MFA (Multi-Fibre Arrangements). Begitu pula dengan ekspor industri kayu lapis atau kayu olahan lainnya, semakinsempit aksesnya untukmasukpasar negara maju yang merupakan konsumen terbesar. Komoditi ini dikenai berbagai pajak bea masuk tambahan. Tak cuma itu, komoditi ini sering pula "diboikot" dengan berbagai kampanye pada masyarakatnya untuk tidak dibeli karena dikaitkan dengan isu per̂sakan lingkungan dan kesehatan.

Jadi hasil dari Putaran Uruguay memberikan harapan agarberbagai tekanan yang menghambat akses ke pasar interiasional itu bisa berkurang. Pasardunia yang terbuka itu diharapkan nantinya menjadi "ajang perburuan" devisa bagi berbagai produk yang memiliki keunggulan kompetitif ataupun komparatif di pasar global. Namun demikian perlu dicatat bahwa senua itu masih berupa peluang, dan peluang tidak hanya milik Indonesia. Negara-negara lain anggota GATT, yang saat itu sebanyak 117 negara, juga menanggapi hasil Putaran Uruguay tersebut sebagai kesempatan untuk meningkatkan perdagangannya, khususnya untuk ekspor mereka.

Dengan demikian, persaingan di pasar dunia juga kian kompetitif, sehingga peluang tersebut baru dapat diaktualkan manakala kita bisa bersaing secara lebih bebäs dan adil di pasar global ini. Di sinilah masalah efisiensi dalam berproduksi memainkan peranan yang sangat penting.

Memang untuk beberapa produk, 
seperti tekstil, alas kaki (footwear products), kayu lapis, kertas dạ beberapa komoditi lainnya, kita sudah cukup efisien dan unggul, sehingga diharapkan dengan hasilPutaran Unuguay tersebut bisa otomatis meningkat volume dan nilai ekspornya. Namun kita tentu tidak puas dengan mengandalkan segelintir komiditi itu saja untuk diekspor, tetapi juga perlu lebih bervariasi dan lebih banyak dalam jenis komoditi baru yang bisa dijual di pasar dunia. Ini merupakan tantangan intemal yang perlu dijawab untuk memanfaatkan pasar global tersebut.

Putaran Uruguay tak hanya berarti terbukanya pasar dunia untuk kita, tetapi juga terbukanya pasar domestik kita untuk negara lain. Ini konsekuensi bági șetiap contracting parties GATT. Artinya, pasar kitajuga akan lebih mudah ditembus barang impor. Berbagai tariff harus diturunkan, yang dalam jangka panjang tinggal berkisar pada tingat 5-10\%. Hambatan-hambatan bukan tarif (non-tarif barriers), seperti pelarangan impor (import prohibition), kuota impor, dan sebagainya, harus dihilangkan dan dikurangi. Dengan demikian; persaingan di dalam negeri akan menjadi lebih ketat.

Memang seniuanya tidak drastis harus dilakukan setelah Hasil Putaran Uruguay diratifikasi, melainkan dilakukan secara bertahap. Namun mau tidak mau kita harus mengantisipasi semua itu sebelum perjanjian itu secara penuh dilaksanakan. Pertanyaan sekarang adalah apakah kita sudah benar-benar siap menghadapi semua itu?

Secara jujurhanus diakui tidaksemua komoditi domestik sudah siap bersaing secara lebih bebas di pasar lokal ini. Untuk industri, sebagaimana kita ketahui, banyak yang masih mendapat perlindungan dari pemerintah. Sementara itu, beberapabidang juga berkembang karena hak monopoli dan oligopoli yang diberikan oleh pemerintah. Hal seperti ini jika terus berlanjut sulit meningkatkan efisiensi dan menusak daya saing páda sektor-sektor itu. Oleh karenanya, berbagai perlindungan yang sifatnya dapat menghambat usaha meningkatkan efisiensi nasional, perlu untuk dievaluasi dan segera dicabut.

Jika kita cermati, pemerintah juga sudah melukan berbagại deregulasi untuk meningkatkan efisiensi ini, seperti yang dilakukan 23 Mei 1995 yanglalu. Berbagai hasilnya juga sudah nampak dan kian -memperbaiki gerak ekonomi nasional. Dengan telah disepakatinya Putaran Uruguay, maka tampaknya kita perlu lebih mempercepat atau melakukan akselarasi deregulasí dan debirokratisasi ekonomi ini. Percepatan untuk mengurangi dan menata aturan-aturan yang dapat menimbulkan distorsi ekonomi dan menghambat jalannya perekonomian secaranormal tersebut bukan saja untuk melindungi produsen domestik agar tidak tergilas oleh industri dari luar yang akan lebih bebas masuk ke Indonesia, melainkan juga dalam rangka, memanfaatkan peluang pasar yang lebih besar di pasar dunia.

Masalahlain yang tampaknya cukup pelik yang dihadapi sebagai konsekuensi hasil dari Putaran Uruguay adalah berkaitan dengan efisiensi dan daya saing produk pertanian. Misalnya saja, salah satu butir dalam Putaran Uruguay ini adalah harus dibukanyapasarproduk pertaniandomestik, paling tidak tiga persen dari konsumsi dalam negerinya. Ini secara bertahap akan 
ditingkatkan menjadi lima persen. Padahal beberapaprodukpertanian kita masihsangat lemah daya saingnya, dan subsektor itu berperan dalam menyerap tenaga kerja yang besar. Jadikalau produkdari luarkompetitif, maka tak boleh ada hambatan untuk masuk ke Indonesia. Ini berlaku pula untuk komoditi beras ataupun gula pasir, dan berbagai produk lainnya. Dalam produkproduk tersebut ada kepentingan kita untuk melindungi produsen dalam negeri. Namun demikian hal itu agaknya tak bisa lagiterismenerusuntuk dilakukan. Karena walaupun kita secara riil sudah swasembada karena produksinya sudah menyamai atau bahkan melebihi permintaan domestik, namun tetap juga harus impor atau membuka pasar untuk sejumlah produk impor manakala harga impor memang lebih murah.

\section{Penutup}

Demikianlah beberapa uraian, catatan dan masalah yang berkaitan dengan telah diratifikasinya Putaran Uruguay, serta kemungkinan implikasinya bagi Indonesia. Hasil dari Putaran Uruguay tersebut menunjukkan pula bahwa akan banyak perubahan-perubahan yang berkaitan dengan hubungan ekonomi antar negara di dunia ini. Perubahan-perubahan tersebut mau tidak mau harus diikuti pula oleh perubahan yang berkaitan dengan aspek hukumnya. Berbagai produk hukum kita juga harus tanggap terhadap berbagai perubahan ekonomi yang cepat tersebut. Artinya, penyesuaian-penyesuaian ketentuan-ketentuan perindang-undangan kita mungkin perlu dilakukan. untuk mengimbangi perkembangan perubahan pesat dalam perekonomian global, regional dan nasional.
Di samping penyeșuaian bidang hukum tersebut, juga dituntut pula adanya ketegasan untuk melaksanakan produk hukum itu. Artinya, law enforcement betulbetul bisa diwujudkan, sehingga dapat meningkatkan disiplin masyarakat, termasuk birokrat. Adalah tidak mungkin membuat strukturekonomi kitaefisien kalau pelaksanaan hukum yang berkaitan dengan bisnis bersifat diskriminatif, atau memihak kepada kepentingan tertentu. Pemihakan kepada konglomerat, misalnya, yang memungkinkan mereka menguasai pasar produk tertentu, - atau bertindak sebagai monopolis ataupun oligopolis dengan konsentrasi pasar yang tinggi, akan dapat menghambat proses peningkatan efisiensi yang pada akhimya membuat produk tersebut tidak berdaya saing terhadap produk buatan negara lain.

\section{Daftar Pustaka}

Departemen Perdagangan, GATT Putaran Uruguay, Jakarta, 1991.

, Tinjauan Perdagangan Indonesia, Jakarta, 1991.

Edy Suandi Hamid, "Putaran Uruguay dan Dilema Beras Indonèsia", Jawa Post, Surabaya, 1993.

, "Indonesia Pasca Putaran Uruguay", Suara Merdeka, Semarang, 1993.

El-Agraa, Ali M, International Economic Integration, MacMillan Press, London, 1988.

Lembaga Pengembangan Manajemen dan Akuntansi FE UMY dan ISEI Yogyakarta, Seminar Nasional GATT dan Implikasinya terhadap Perekonomian Indonesia, Yogyakarta, 18 Juni 1994. 
Miranda Goeltom, "Esensi dan Dampak Putaran Uruguay terhadap Perekonomian Indonesia", dalam Warto BRI, 1994.

Patricck, C.H dan Nixson FI, Industrial Structure and Policy in Less Developed Countries, George,Allen and Unwin,

London, 1984.

Republika Indonesia, Terjemahan Resmi Persetujuan Akhir Putaran Uruguay, 1994.

Soedradjat Djiwandono. Perdagangan dan Pembangunan, LP3ES, Jakartia, 1992. 